\title{
Winter Rapeseed in the Autumn and Spring Growing Seasons in the Republic of Ingushetia
}

\section{Lisa Kostoyeva1,2, Magomed Bazgiev, Aza Leimoeva1,2, and Mikhail Archakov ${ }^{1}$}

${ }^{1}$ FGBNU Ingush Agricultural Research Institute, Sunja, the Republic of Ingushetia

${ }^{2}$ FGBOU Ingush State University, Magas, the Republic of Ingushetia

ORCID:

Lisa Kostoyeva: http://orcid.org/0000-0002-2258-3724

Aza Leimoeva: http://orcid.org/0000-0003-2144-5618

Magomed Bazgiev: http://orcid.org/0000-0002-7529-6171

Corresponding Author:

Lisa Kostoyeva

kostoevaliz@yandex.ru

Published: 5 April 2021

Publishing services provided by

Knowledge E

(c) Lisa Kostoyeva et al. This article is distributed under the terms of the Creative Commons

Attribution License, which

permits unrestricted use and

redistribution provided that the

original author and source are

credited.

Selection and Peer-review under the responsibility of the DonAgro Conference Committee.

\section{Abstract}

This article examines the varieties and effectiveness of fertilizers for winter rapeseed, the dynamics of the production process of crops at different sowing times, and the influence on the yield of oilseed fertilization of crops, the green mass of which was used for feed in the autumn growing season. The study and optimization of the assortment, research and development of technologies for growing highly productive crops of winter rapeseed is crucial. In this article, the authors summarize the literature and substantiate new directions for the use of winter rape crops for green fodder and oilseeds in different countries and regions of the Russian Federation. The article studies three domestic varieties of the All-Russian Research Institute of Oilseeds named after academician V.S. Pustovoit and one variety of foreign selection. The article identifies the dynamics of biomass accumulation and changes in the morphometric parameters of winter rape plants in the autumn growing season, depending on the timing of sowing. It also studies the productivity and quality of the green mass of winter rape and the possibility of using it for forage purposes. It discusses the yield of winter rape oilseeds, in which the green mass was used in the fall of the sowing year. It also determines the economic efficiency of cultivating the same crops of winter rape used for green mass in the fall and for oilseeds in the spring growing season.

Keywords: winter rapeseed, fertilizers, green mass, oil seeds, vegetation, varieties

\section{Introduction}

Winter rapeseed is a valuable crop, harvest of which can be used in various economic directions. Cultivation of winter rapeseed meets the needs of the development of animal husbandry, and the production of vegetable oil for food, paint and varnish, perfumery, 
crops for biofuel production have been increasing at an ever-increasing pace. For the first time, studies were carried out to develop and test a new direction of economic use of winter rapeseed crops in the zone of non-traditional cultivation of this crop; establishing the nature and degree of variability in the productivity of varieties, depending on the timing of their sowing and the conditions of the growing season; plant reactions to the spring application of nitrogen and nitrogen-phosphorus mineral fertilizers in case of alienation of a part of the green mass in the fall. Thus, the possibility of multilateral use of the same crops for various economic purposes is justified for green fodder and oil seeds. The purpose of the research is to select a strategy for the application of technological methods for the cultivation of winter rapeseed in the land-poor Republic of Ingushetia and expands the range of further research in the region. [1-3].

\section{Methods and Equipment}

\subsection{Methods}

In 2017-2019 In the Republic of Ingushetia, field experiments were carried out on the cultivation of winter rapeseed on the experimental plot of the Ingush Scientific Research Institute of Agriculture. (Figure 1). The soil of the experimental site is weakly leached chernozems - medium-thick, medium-loamy. The thickness of the humus horizon is 46$60 \mathrm{~cm}$. In the areas, the humus content was from 4.80 to $4.90 \%$. The provision with mobile forms of $\mathrm{P}_{2} \mathrm{O}_{5}$ is $22.5-26.0 \mathrm{mg} / \mathrm{kg}$ of soil, potassium - from 330 to $345 \mathrm{mg} / \mathrm{kg}$. In terms of agrochemical and agrophysical properties, the soil is favorable for growing winter rapeseed.

During the growing seasons of the first two sowing periods, there was a lack of moisture in the soil against a background of air temperatures above the perennial average.

The research identifies the influence of the sowing time and the nutritional background on the productivity of early crops of winter rape for forage use in the foothill zone of the Republic of Ingushetia.

It studies the influence of sowing time, background of nutrition and width of row spacing on the growth and development of plants. The research scheme included the following factors and their variants: factor A - sowing dates: first - (July 20-22), second - (August 5-7), third - (August 20-22); fourth control - (sowing September 13-15); factor B background nutrition: 1. - N60; 2. - N90; 3. -N60 P30; 4. - (NP) 60; 5. - Control, without spring feeding; factor $\mathrm{C}$ - varieties of winter rapeseed: Dragon, Meteor, Onyx, Elva. [4, 5]. 


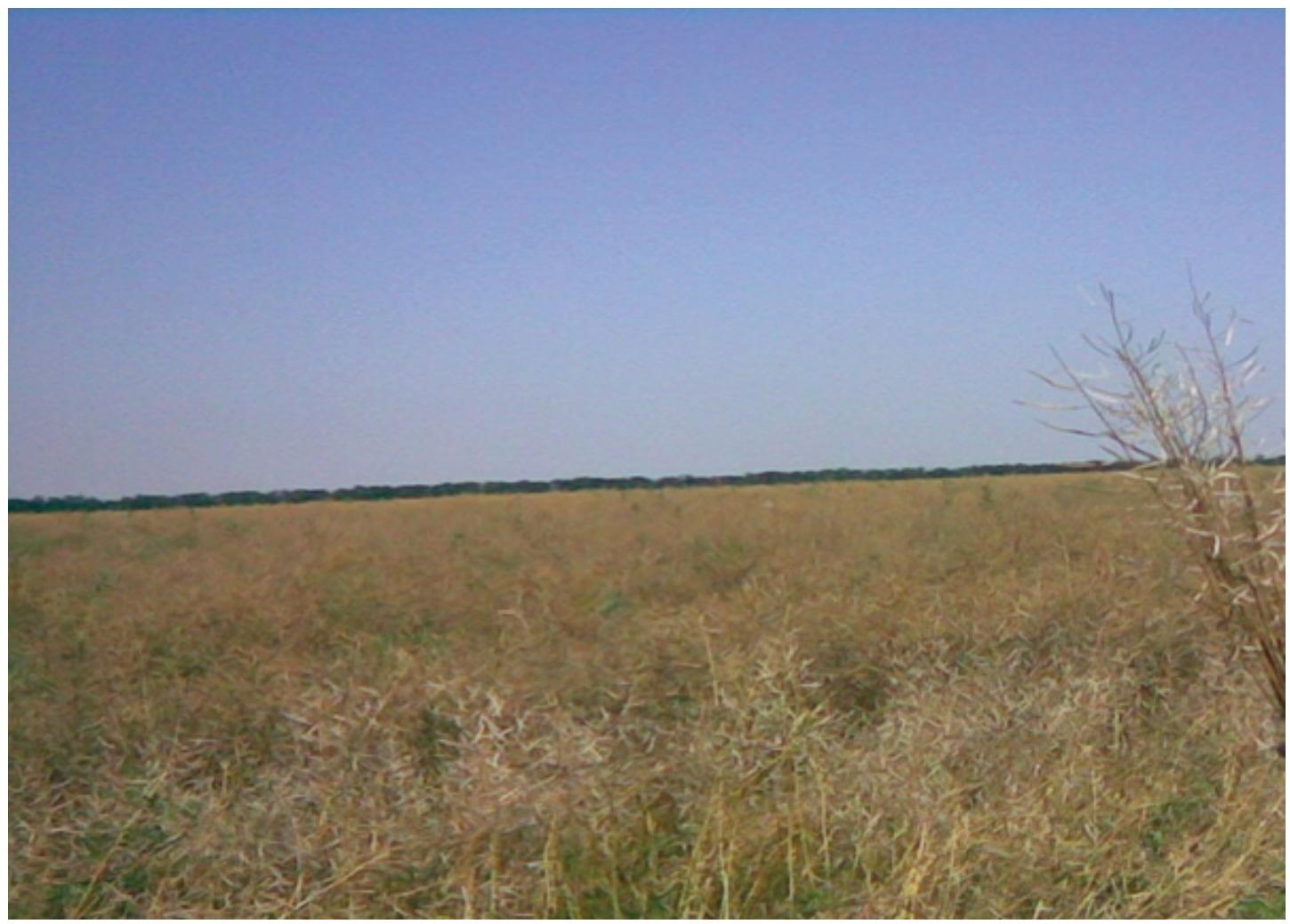

Figure 1: Experimental plot with crops of winter rape in the fruiting phase)

The generally accepted agrotechnology of cultivation was used during the study. While cultivating highly productive varieties of winter rape, we studied the dynamics of the crop production process at different sowing dates: September 10-12 (control), July 20-22, August 5-7, August 20-22, and the green mass is harvested sequentially after 10 -15 days, as the stage of cutting ripeness is reached and the green mass is harvested sequentially after 10-15 days, as the stage of cutting ripeness is reached. [6.7]

\subsection{Equipment}

The research objects were the varieties of winter rapeseed: Dragon, Meteor, Onyx, Elva.

\section{Results}

The productivity of early crops of winter rapeseed for use for forage purposes in the foothill zone of the Republic of Ingushetia was established during 2017, 2018 and 2019. Experimental options: 1. sowing July 20-22; 2. August 5-7; 3. August 20-22; 4. Control sowing September 13-15. The variation in sowing dates is caused by weather conditions. We tested four varieties of winter rapeseed (Dragon, Meteor, Onyx, Elva). For each 
variety, 15 days after sowing, field germination records were carried out. In the autumn growing season, 20,30, 40 and 50 days after sowing, the number of developed plants per 1 square meter of crops was taken into account; the number of leaves in one rosette, the leaf area was determined. The aforementioned counts and measurements were carried out on fixed in nature accounting sites measuring $1 \times 1 \mathrm{~m}$. At the same sites, the parameters of the aboveground part were measured. As a result of measuring the diameter of the rosette of the studied varieties, depending on the timing of sowing, and after the same periods from the beginning of the growing season, we identified the features of the dynamics of this process (Figure 2).

The data presented indicate that during the first 20 days of the growing season, the most active growth was observed in August sowing of winter rape. The July crops are somewhat inferior to the August crops, especially those carried out in the second decade. The sowing of winter rape, carried out in September, is significantly inferior in terms of growth activity, both in August and in July, which we associated with a lack of heat in the second decade of September, the first and second decades of October.

The sowing of winter rape, carried out in September, is significantly inferior in terms of growth activity, both in August and in July, which we associated with a lack of heat in the second decade of September, the first or second decades of October. The 3-year average values of the change in leaf area according to the growing season after the emergence of seedlings show that the maximum increase is observed in option 3.

In each of the years of research, the early sowing of all varieties of winter rape by the time of mowing of the aboveground mass had a leaf surface more than 2 times larger than the sown area. The development of the leaf surface is a direct indicator of the formation of the assimilation apparatus of winter rapeseed in the autumn growing season. [6, 7]. Accounting for the growth of the aboveground mass and roots over certain periods of time clearly represents the course of the production process, which can be expressed in a unit of biomass for the noted growing season. (Figure 3).

The analysis of the given data for the years of observation shows that all the tested variants of the sowing time of each of the studied varieties were in all years more productive than the control ones (Figure 4).

Figure 5 shows visual indicators of the change in the share of green fodder mass in the total aboveground part of various varieties in comparison with the standard for options for sowing dates.

In general, the total yield of green mass in the studied varieties during autumn and spring mowing exceeds the level obtained on control crops (Fig. 6). 


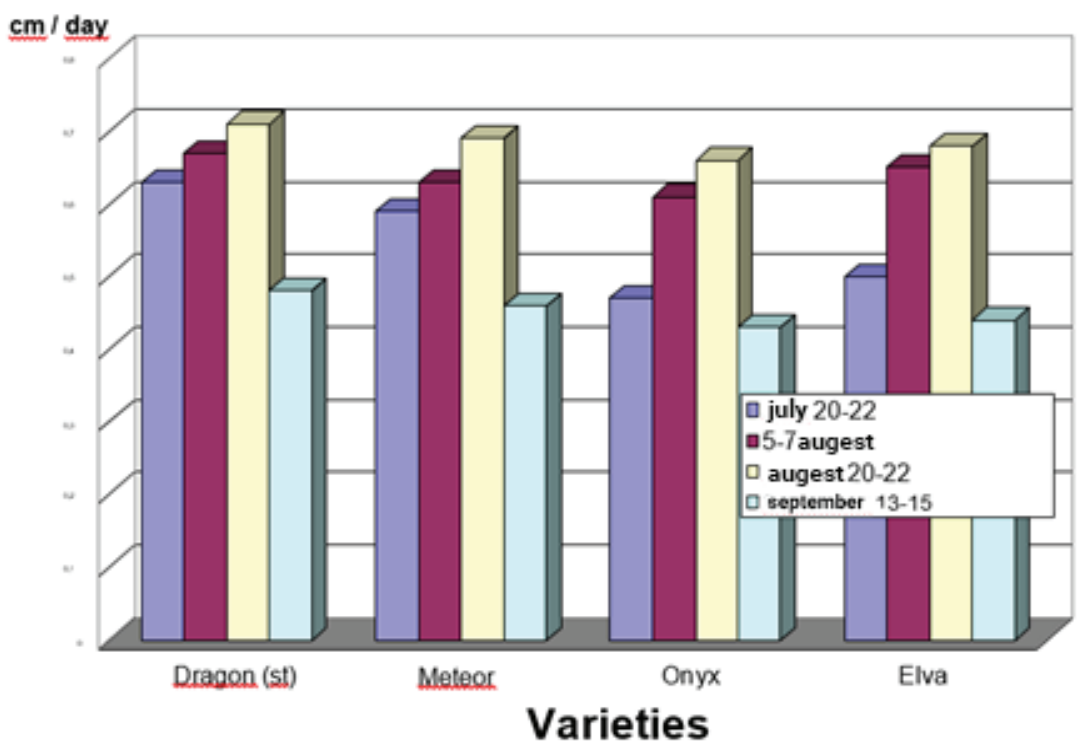

a

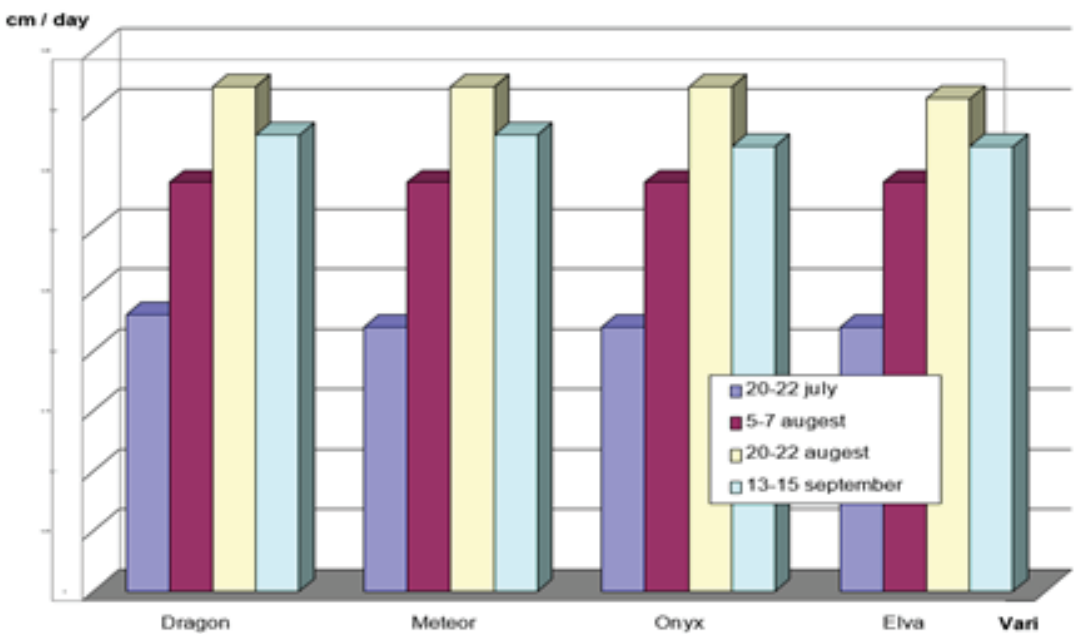

b

Figure 2: (a) Average daily growth of the rosette diameter of winter rape varieties depending on the sowing time. (b) Average daily autumn growth of the rosette of winter rape varieties, depending on the sowing time for the entire growing season. Growth of the rosette diameter $(\mathrm{cm})$ of winter rape plants depending on the sowing time. Average over 3 years

It can be seen from the above data that the yield of green fodder mass varies on average over 3 years according to the variants of the experiment in the range from 2.6 to $8.1 \%$ in relation to the control.

Due to the fact that stems predominate in the green mass of spring mowing, and leaves make up less than $25 \%$ of the yield, an important point is to assess its quality (Table 1). 


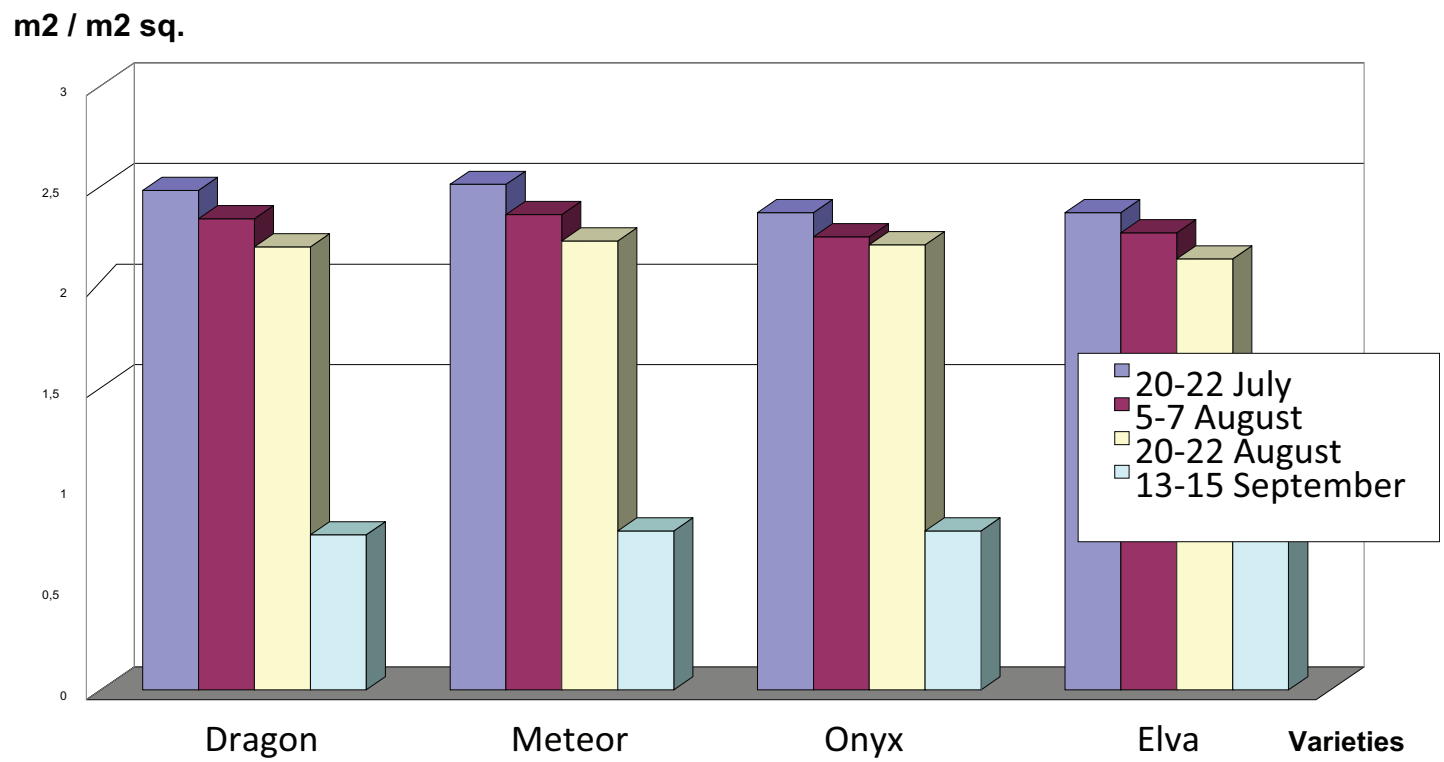

Figure 3: The total leaf area of winter rape varieties depending on the sowing time. Average over 3 years. As of October $18-20$

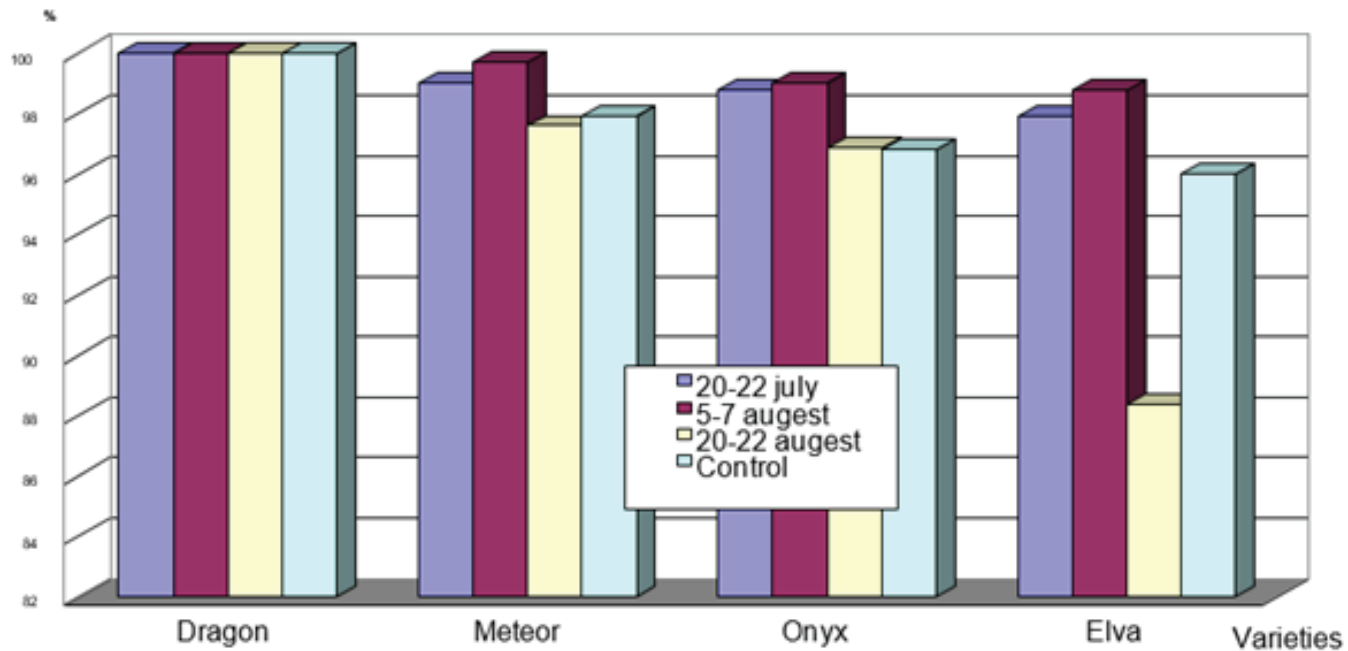

Figure 4: Change in the weight of the aboveground part of the studied varieties by sowing time. Average over 3 years

As a result of studying seed productivity for three years, we identified certain patterns in the change of not only quantitative but also qualitative characteristics of the crop. [6] It was found that as the sowing time is delayed, all studied varieties have an increase in seed yield (Table 2).

The revealed regularities of a decrease in the yield of winter rapeseed in crops at an early date in comparison with the control is mainly associated with a significant change in the structure of the aboveground parts of individual plants (Fig. 7). 


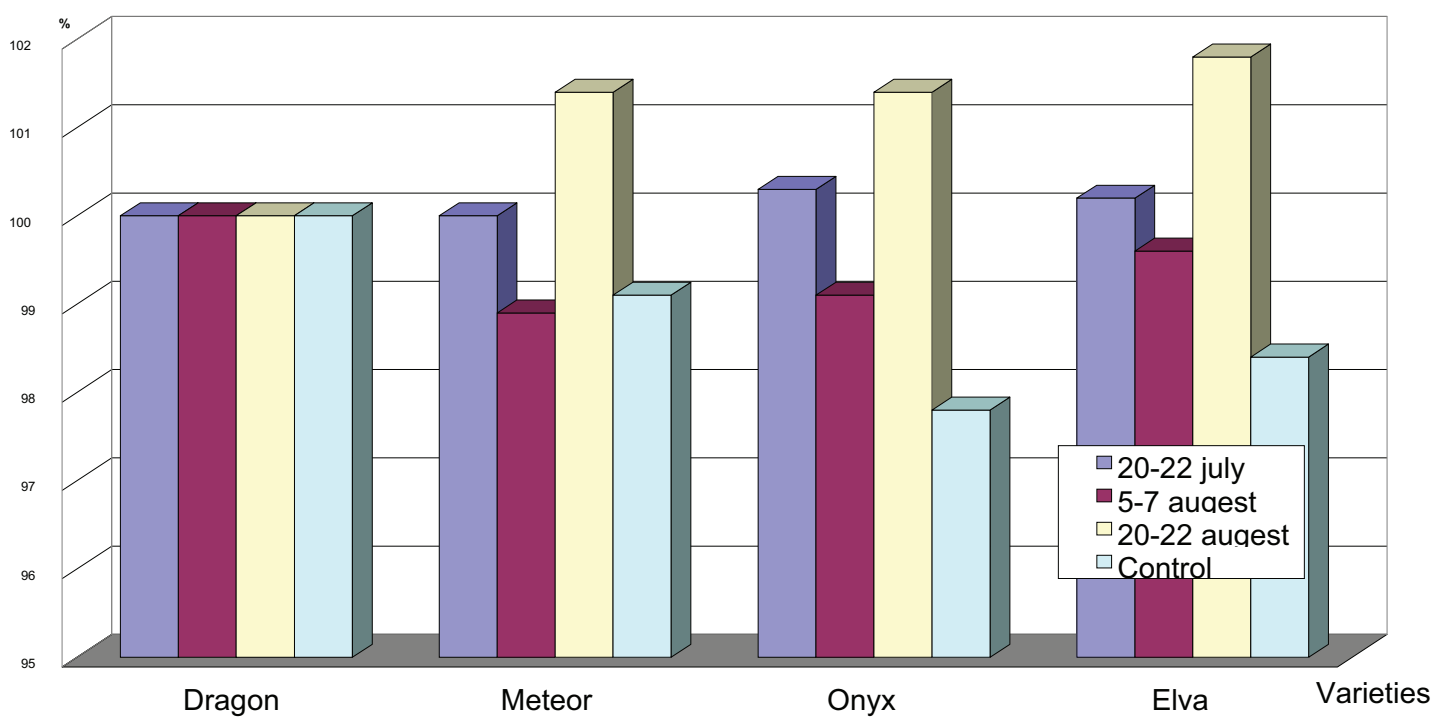

Figure 5: Changes in the yield of forage green mass in different varieties depending on the sowing time in comparison with the standard. Average over 3 years

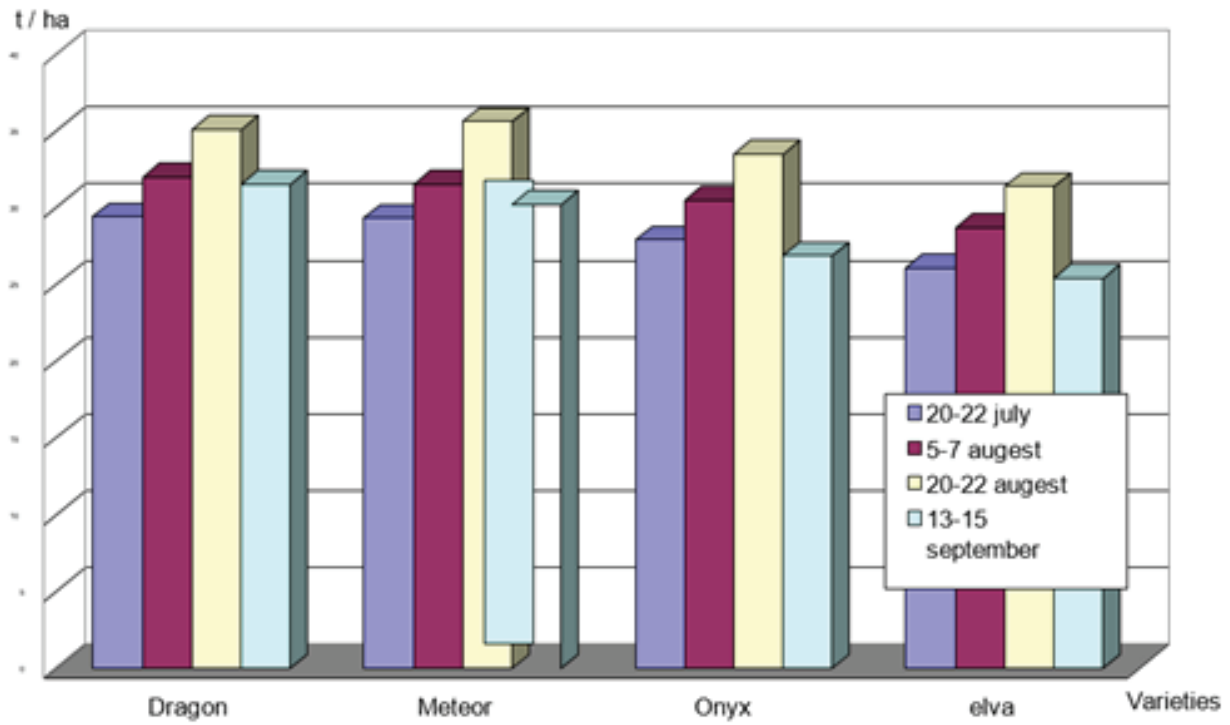

Figure 6: The total yield of green mass for autumn and spring cuttings, depending on the timing of sowing winter rape

Using the example of the standard Dragon varietyit can be seen that the earlier the sowing is carried out, the more shoots are formed from the axillary buds on one plant. The pods developed on one plant of winter rape are also closely related. The close relationship between these indicators is evidenced by the corresponding trend lines, which have not only a homogeneous polynomial curve, but also practically coincide in relative quantitative parameters. 
TABLE 1: The content of nutrients in the green mass of winter rape of different sowing dates as of the second decade of April. Average data for 2017-2019.

\begin{tabular}{|c|c|c|c|c|c|c|c|}
\hline \multirow[t]{2}{*}{ Sowing timing options } & \multirow[t]{2}{*}{ Varieties } & \multicolumn{6}{|c|}{ Nutrient yield,\% } \\
\hline & & moisture & protein & fat & cellulose & $\begin{array}{l}\text { nitrogen- } \\
\text { free } \\
\text { extrac- } \\
\text { tive } \\
\text { fraction }\end{array}$ & ash \\
\hline \multirow[t]{2}{*}{ July 20-22 } & Dragon (st) & 83,7 & 3,3 & 1,0 & 7,7 & 2,3 & 1,9 \\
\hline & Meteor & 84,1 & 3,1 & 1,1 & 7,5 & 2,5 & 1,8 \\
\hline \multirow[t]{2}{*}{ 5-7 August } & The Dragon & 83,5 & 3,4 & 1,1 & 7,8 & 2,5 & 1,9 \\
\hline & Meteor & 83,8 & 3,2 & 1,1 & 7,7 & 2,1 & 1,9 \\
\hline \multirow[t]{2}{*}{ August 20-22 } & The Dragon & 84,0 & 3,2 & 1,1 & 7,6 & 2,3 & 1,8 \\
\hline & Meteor & 83,8 & 3,3 & 1,1 & 7,7 & 2,2 & 1,9 \\
\hline \multirow{2}{*}{$\begin{array}{l}\text { September 13-15 } \\
\text { Control }\end{array}$} & The Dragon & 83,6 & 3,2 & 1,1 & 7,7 & 2,6 & 1,8 \\
\hline & Meteor & 83,7 & 3,3 & 1,1 & 7,5 & 2,5 & 1,9 \\
\hline
\end{tabular}

TABLE 2: Yield of seeds of winter rape by varieties and years of cultivation

\begin{tabular}{|c|c|c|c|c|c|c|}
\hline \multirow{2}{*}{$\begin{array}{l}\text { Sowing timing } \\
\text { options }\end{array}$} & \multirow[t]{2}{*}{ Varieties } & \multicolumn{3}{|c|}{ Seed yield by years, $\mathrm{t} / \mathrm{ha}$} & \multicolumn{2}{|c|}{ Average over 3 years } \\
\hline & & 2017 & 2018 & 2019 & tha & in $\%$ to contro \\
\hline \multirow[t]{4}{*}{ July $20-22$} & Dragon (st) & 1,32 & 1,54 & 1,46 & 1,43 & 73,3 \\
\hline & Meteor & 1,38 & 1,52 & 1,45 & 1,45 & 72,1 \\
\hline & Onyx & 1,21 & 1,37 & 1,28 & 1,29 & 71,3 \\
\hline & Elva & 1,15 & 1,29 & 1,23 & 1,22 & 73,9 \\
\hline \multirow[t]{4}{*}{ 5-7 August } & The Dragon & 1,48 & 1,63 & 1,61 & 1,56 & 80,0 \\
\hline & Meteor & 1,54 & 1,60 & 1,58 & 1,57 & 78,1 \\
\hline & Onyx & 1,35 & 1,52 & 1,51 & 1,46 & 80,7 \\
\hline & Elva & 1,24 & 1,33 & 1,27 & 1,28 & 77,6 \\
\hline \multirow[t]{4}{*}{ August $20-22$} & The Dragon & 1,52 & 1,73 & 1,66 & 1,63 & 83,6 \\
\hline & Meteor & 1,56 & 1,69 & 1,64 & 1,63 & 81,1 \\
\hline & Onyx & 1,49 & 1,58 & 1,55 & 1,54 & 85,1 \\
\hline & Elva & 1,32 & 1,41 & 1,38 & 1,37 & 83,0 \\
\hline \multirow{4}{*}{$\begin{array}{l}\text { Control, } \\
\text { September } \\
13-15\end{array}$} & The Dragon & 1,86 & 2,03 & 1,96 & 1,95 & 100 \\
\hline & Meteor & 1,94 & 2,07 & 2,02 & 2,01 & 100 \\
\hline & Onyx & 1,73 & 1,88 & 1,82 & 1,81 & 100 \\
\hline & Elva & 1,59 & 1,71 & 1,66 & 1,65 & 100 \\
\hline \multicolumn{2}{|c|}{ HCPO5 for st by options } & - & - & - & 0,18 & - \\
\hline
\end{tabular}

As a result of early sowing with autumn mowing of the aboveground part, bushy plants are formed; this fact leads to significant changes in the morphology of winter 
rapeseed. This situation has a significant effect 1 on the structure of the crop and on the yield of seeds from one pod and the mass of 1000 pieces (Fig. 8). [5.6].

Number of shoots, pcs

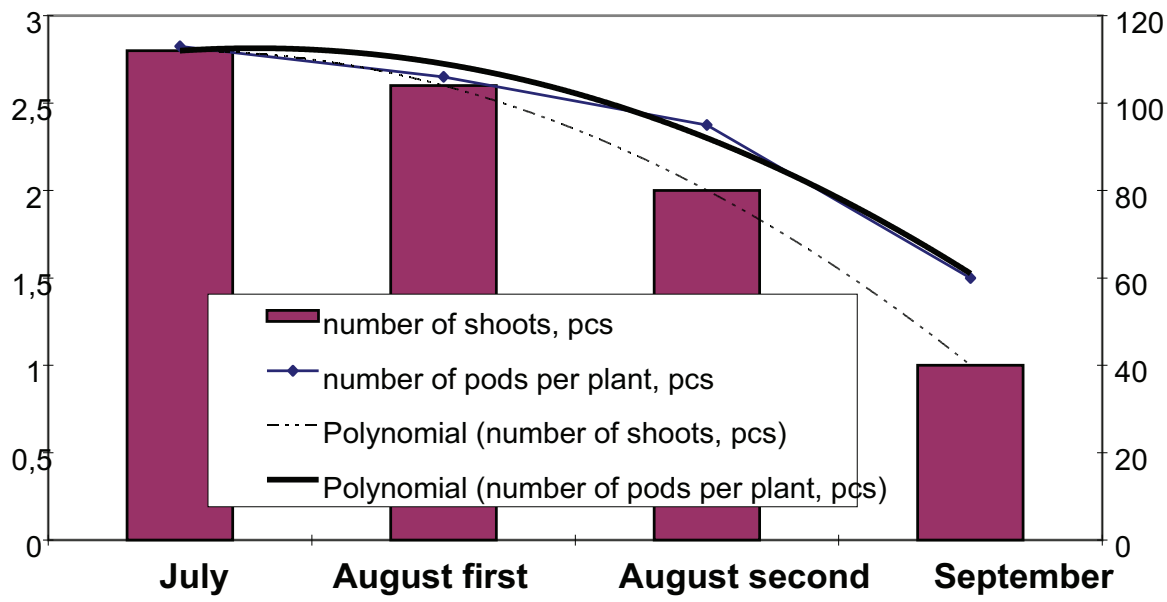

Number of pods, pcs

Figure 7: Change in the number of shoots in a bush and pods on one plant Depending on the yield dates

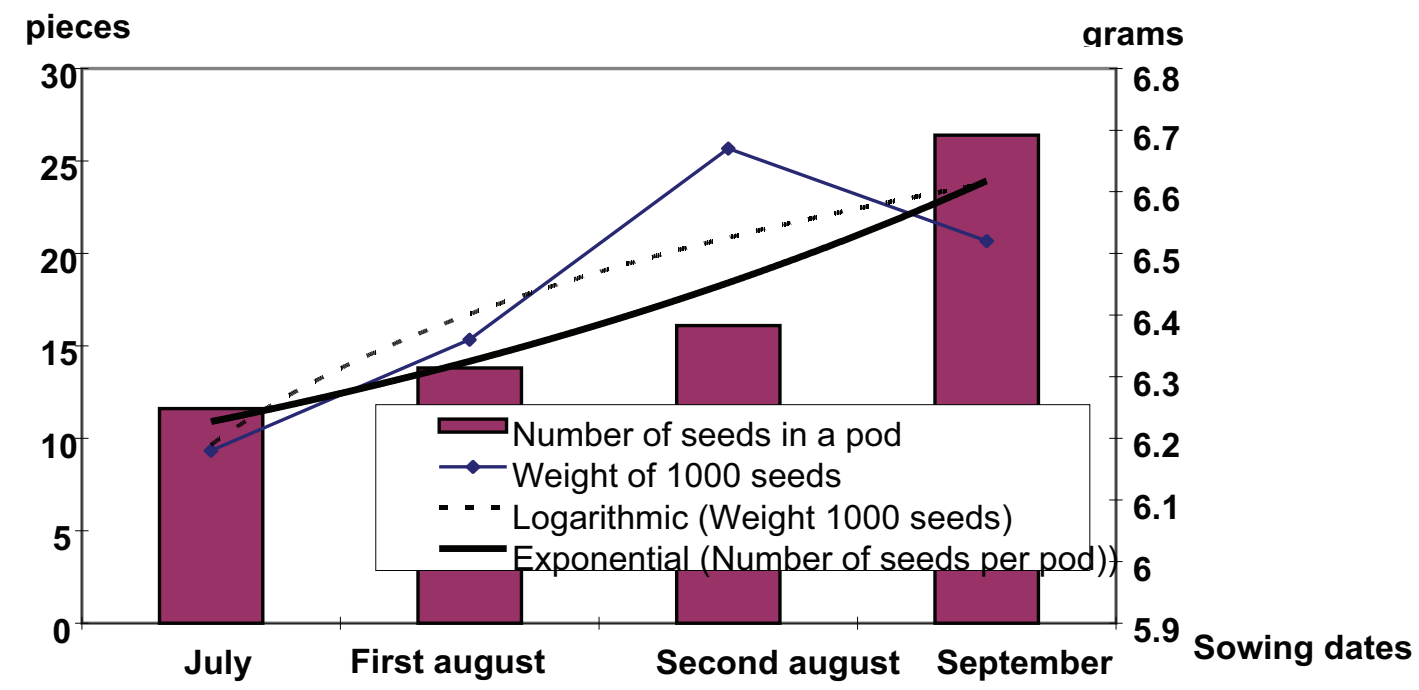

Figure 8: Change in the number of seeds in a pod and their mass of 1000 pieces, depending on The yield dates. Dragon. 2d year

The analysis of the given data shows that the number of seeds in one pod is the greater, the later the sowing of winter rape carried out. At the same time, an inverse close relationship was revealed between the number of shoots on one plant on the one hand and the content of seeds in the pods: $r=-0.83+0.11$. The correlation between the number of developed shoots and the number of pods per plant is somewhat weaker: $r$ 
$=-0.68+0.17$. As can be seen from the values of the correlation coefficient, its negative value indicates an inverse relationship.

The tendency for changes in the average weight of 1000 seeds indicates a character similar to changes in the number of seeds in a pod.

\section{Discussion}

One of the determining factors for increasing the yield of winter rapeseed seeds is early autumn sowing without autumn mowing of the aboveground mass. At the same time, the autumn and spring mowing of the green mass of the August crops allows getting a higher yield than a single mowing in the spring.

Based on the calculation of economic efficiency, it can be concluded that the cultivation of winter rapeseed for seeds provides a profit that is 1.7 - 2.3 times higher than for green mass. At the same time, the pattern of change in profit is similar to the pattern of growing rapeseed for green mass. Seed productivity in crops of different dates tends to increase as the planting date approaches the control. The low seed productivity of early crops is associated with the high shoot-forming ability of winter rape plants, which causes a decrease in pods and the number of seeds in them.

The green mass of the autumn growing season is distinguished by high protein content (3.1-4.4\%) and low fiber content (less than 3.2\%). In early crops, the fiber content is 2-3 times higher than in September, control crops. The varietal differences in the nutritional properties of the green mass of winter rape are insignificant.

\section{Conclusion}

Thus, in order to obtain high yields of both green mass and oil seeds in the foothill zone of the Republic, it is necessary to sow winter rapeseed in the second period of August. Of the options for fertilizing winter rape crops, the best one is the introduction of 90 $\mathrm{kg} / \mathrm{ha}$ of nitrogen fertilizers. In this case, a high efficiency of growing winter rape is achieved not only for green mass, but also for seeds in more significant volumes.

\section{Acknowledgement}

These studies were carried out on the basis of the Ingush Scientific Research Institute of Agriculture. 


\section{Confirmation}

The authors are grateful to their colleagues and reviewers for their contribution and support in the study, for help in completing the work.

\section{Conflict of Interest}

The authors have no conflicts of interest to declare.

\section{References}

[1] Akhlopov, K. A. and Bulikin, V. I. (2004). Problems of Oilseed Production in the South of Russia. Problems of Plant Resources. In Materials of the International Research and Production Complex, September 2004. Vladikavkaz: GGAU, pp. 38-40.

[2] Belyak, V. V., Semenova, E. F. and Brazhnikov, V. N. (1998). Oilseeds on Leached Chernozems. Feed Production, vol 9 issue 9, pp. 26-28.

[3] Govorov, S. A. (2003). Winter Rapeseed as a Multipurpose Crop. Agriculture, vol 4 issue 4 , pp. 18-19.

[4] Govorov, S. A. (2001). Varieties of Winter Rapeseed for Feed and Oilseeds. Feed Production,vol 11 issue 11, pp. 24-25.

[5] Shmal, V. V. (2000). New Promising Varieties and Hybrids of Oilseeds. Agriculture, vol 4 issue 4, pp. 40-41.

[6] Zherukov, B. K., Govorov, S. A. and Fisun, M. N. (2000). Forage Oilseeds in KabardinoBalkaria. Nalchik: KBGSKhA, p. 19.

[7] Kostoeva, L. Y. (2009). Winter Rapeseed in the Foothill Zone of the Republic of Ingushetia. International Agricultural Journal, vol 3 issue 3, pp. 60-61. 